\title{
Repatriation of sacred indigenous cultural heritage and the law
}

Citation for published version (APA):

Tünsmeyer, V. M. (2020). Repatriation of sacred indigenous cultural heritage and the law: Lessons from the United States and Canada. [Doctoral Thesis, Maastricht University]. Maastricht University. https://doi.org/10.26481/dis.20201022vt

Document status and date:

Published: 01/01/2020

DOI:

10.26481/dis.20201022vt

Document Version:

Publisher's PDF, also known as Version of record

\section{Please check the document version of this publication:}

- A submitted manuscript is the version of the article upon submission and before peer-review. There can be important differences between the submitted version and the official published version of record.

People interested in the research are advised to contact the author for the final version of the publication, or visit the DOI to the publisher's website.

- The final author version and the galley proof are versions of the publication after peer review.

- The final published version features the final layout of the paper including the volume, issue and page numbers.

Link to publication

\footnotetext{
General rights rights.

- You may freely distribute the URL identifying the publication in the public portal. please follow below link for the End User Agreement:

www.umlib.nl/taverne-license

Take down policy

If you believe that this document breaches copyright please contact us at:

repository@maastrichtuniversity.nl

providing details and we will investigate your claim.
}

Copyright and moral rights for the publications made accessible in the public portal are retained by the authors and/or other copyright owners and it is a condition of accessing publications that users recognise and abide by the legal requirements associated with these

- Users may download and print one copy of any publication from the public portal for the purpose of private study or research.

- You may not further distribute the material or use it for any profit-making activity or commercial gain

If the publication is distributed under the terms of Article $25 \mathrm{fa}$ of the Dutch Copyright Act, indicated by the "Taverne" license above, 


\section{Summary}

\section{Repatriation of Sacred Indigenous Cultural Heritage and the Law V.M. Tünsmeyer}

\section{Defence 22.10.2020 at 12:00 hours}

This study analyses the repatriation of sacred indigenous cultural heritage in the laws of the United States and Canada. The question of whether to return heritage to indigenous communities (referred to in the research as repatriation), and if so how, has occupied museums and policymakers for decades. In Europe, the debate has received (re)new(ed) attention in the recent years, with the promise made by Macron, new repatriation guidelines in Germany and the Netherlands, and a number of reports published on the matter. By contrast, in the United States, the repatriation movement was strengthened with the adoption of a federal mandatory legislation in 1990. In Canada, no action was taken on the federal level, but provinces approached the matter differently. In particular, the approach taken in Alberta and British Columbia were considered in more detail, and the advantages and disadvantages compared.

The research therefore aims to consolidate the lessons that exist from almost 30 years of regulating repatriation through the law, to facilitate the work of actors who are now about to engage in repatriation. Moreover, it combines this research with a normative framework, distilled from international human rights and international cultural heritage law, with a view to help policy makers and museums to better align future repatriation frameworks with contemporary human rights standards.

This is reflected in the research questions posed at the outset, namely how should the repatriation of sacred cultural heritage be regulated in light of international human rights and cultural heritage law standards? And second, is there anything else we can derive from these findings for the national cultural heritage law and policy of Canada and the United States? Since the adoption of the first legal instruments that regulated the repatriation of indigenous cultural heritage a lot has changed, in particular in the indigenous rights movement. To reflect these changes and provide recommendations that are based not only on experience but also are up to date in light of legal advances that were made in the meantime, the author analyses the repatriation laws in light of international human rights law. This is crucial, as there is continued reticence of state actors to align international cultural heritage law with human rights standards, and this has impacted indigenous peoples in particular.

Based on the analysis of contemporary international human rights and international cultural heritage law the author derived human rights guidelines which were then used to analyse the national legal frameworks. On this basis nine repatriation-specific guidelines were developed that are presented in section I below. Moreover, the analysis yielded different models to structure repatriation, depending on the aim pursued and whether the return is an international one or occurs within one legal system (presented in section II). The research also yielded a number of important lessons for the national cultural heritage law and policy of Canada and the United States (briefly summarized in section III). 


\section{Standards derived from international law}

Cultural heritage is an important resource for a wide range of human rights. This connection has been highlighted on the international level, inter alia through the works of the Special Rapporteur in the field of cultural rights. Unsurprisingly, repatriation of cultural heritage affects a number of indigenous rights, and the research that was undertaken has clarified this connection. In particular, we have seen how repatriation of sacred heritage can be a measure that a state can take to strengthen a number of different rights, including the indigenous right to cultural heritage and the indigenous right to their religious practices. Furthermore, the research emphasized that human rights law also demands certain elements to be included in a repatriation framework to respect and protect different rights. In international human rights law, there is no state obligation to repatriate sacred heritage. However, repatriation is a means to realize a number of obligations that a state has towards the indigenous peoples within its territory. First, it complies with duty to fulfil the freedom to manifest religion; an alternative measure to fulfil this right would be to guarantee indigenous access and use of sacred objects that are under governmental control. Second, it fulfils the indigenous right to minority culture, including the right to control cultural heritage. Third, it is a measure to protect and fulfils the indigenous right to their cultural identity, including the right to revitalize their cultural traditions.

In the course of the analysis, more general human rights standards were drafted, which were derived by considering the relevant treaty articles and their relationship to repatriation. ${ }^{1}$ This analysis was informed by the general comments of the respective treaty bodies, the reports of different special rapporteurs and expert committees. Because of the broadness of the relevant cultural rights articles and the specific nature of repatriation and indigenous cultural practices, the observations in part I were still rather broad in nature. The standards derived in Part I were therefore applied to the outcomes of the national legal analysis. This yielded a nine more specific guidelines. These principles operationalize indigenous cultural rights for the actors who engage in repatriation and may be unfamiliar with the specifics of the human rights canon.

\section{I.1. Repatriation-specific guidelines}

These guidelines can be structured in accordance with the procedure of adopting a repatriation law. This means that there are human rights standards and obligations which have to be respected in the drafting phase of the law, those that have to be incorporated into the repatriation legislation itself, and those which need to be respected in the implementation of the repatriation legislation. These are indicated below.

\section{Drafting phase}

1. The repatriation framework itself should be developed in cooperation with the indigenous peoples concerned. It is important to collaborate with indigenous peoples to ensure respect for different indigenous cultural rights that can be affected by the framework. This operationalizes different elements of a number of rights, in particular Art.11(2) UNDRIP and Art.38 UNDRIP.

\footnotetext{
${ }^{1}$ See chapter 2 for standards and the human rights provisions on which they are based, in particular section VI.1.
} 


\section{Repatriation legislation}

- Scope -

2. Respect indigenous beliefs in the definition of religious object by respecting indigenous authority and practices to identify sacredness. Interference with indigenous religious practices only permissible under the (very narrow) conditions of Art.18(3) ICCPR and the additional limitation imposed by Art.27 IRCCPR.

3. Respect the indigenous right to self-identification; do not impose a governmental definition of indigenous identity that is contrary to indigenous self-identification. The definition of indigenous peoples used may not exclude indigenous peoples within the territory who identify as indigenous in line with Art.33(1) UNDRIP.

- Regulating repatriation procedure -

4. In connecting a sacred object to a community, indigenous customary legal traditions should be respected. If scientific methods are used to connect objects to communities' actors should obtain FPIC for measures that affect indigenous cultural rights.

5. The repatriation framework should not require a continuing practice between initial practice and the time of reclaiming if the object is reclaimed for contemporary use. This is an important safeguard to ensure that a state respects the indigenous right to revitalization. This is also part of the fulfil dimension of freedom of religion. A decision not to repatriate must therefore be permissible under the relevant limitation clauses of Art.27 ICCPR and Art.18(3) ICCPR.

6. Respect indigenous rights to their own legal traditions by incorporating indigenous customary practices within a repatriation framework if these are in accordance with international human rights law. Examples of measures that can be taken in accordance with indigenous legal traditions are

a. identify linkage between object and community,

b. identification of custodian of heritage,

c. incorporation of oral testimony where relevant.

\section{Implementing repatriation legislation}

7. Identifying indigenous cultural heritage should be done in consultation with indigenous peoples to guarantee Art.31 UNDRIP.

8. Do not dictate conditions for indigenous peoples to fulfil upon the repatriation of sacred objects in order to respect indigenous right to their own heritage under Art.31 UNDRIP.

9. Sacred heritage in public collections that is not repatriated must be made accessible to indigenous religious practitioners in private, in accordance with Art.12(1) UNDRIP and Art.18(1) ICCPR.

\section{I.2. Standards arising out of international cultural heritage law}

The first research question employs international human rights law and international cultural heritage as a measuring standard by which to evaluate repatriation legislation. The guidelines elaborated above, however, are based on human rights law alone. As was seen in chapter 3, international cultural heritage law does not oblige states to return cultural heritage taken during colonialism to indigenous communities, either abroad or within their own territory. However, existing ICHL instruments incorporate provisions that do affect intra-national repatriation. The 
most concrete example of a return obligation for sacred indigenous heritage exists in the 1995 UNIDROIT Convention. However, it applies to sacred objects that leave the country after the Convention entered into force, and therefore it is not applicable to colonial sacred cultural heritage (unless the latter is taken outside of the community for a second time).

However, the repatriation of sacred objects, or alternatively access and use agreements, can be classified as one of the possible measures that a state has to take to fulfil its obligations under the 2003 UNESCO Convention and under the 2005 UNESCO Convention. Under the respective Convention, the state is obliged to take measures to protect intangible cultural heritage and the diversity of cultural expressions. Measures that ensure indigenous access to and use of sacred cultural heritage, including repatriation, can be classified as measures that achieve both objectives. Under the 2003 Convention, the artefacts fall under the scope of the convention because of their connection to the protected ritual. Under the 2005 Convention, access to their cultural heritage is a possible measure expressly considered by the convention. Repatriation, if understood as a measure to strengthen indigenous cultures, promotes and protects the diversity of cultural expressions, which is an express objective of the convention. ${ }^{2}$ In both cases, the conventions do not create an obligation to take the specific measures that are the focus of this research. Rather, the state is under a general obligation to achieve the objectives of the conventions and, in line with the particular treaty provisions, repatriation or access and use agreements qualify as measures to achieve these objectives. The measures that a state may have to take under international human rights law go far beyond what a state is legally required to do under the UNESCO instruments. For this reason, it was sufficient to apply the principles developed in chapter 2 to evaluate the three repatriation examples in chapters 4 to 8 .

\section{Different mechanisms to regulate repatriation in light of international standards}

As chapter 9 and the comparative analysis of the different repatriation laws show, there are different ways (models) in which repatriation can be structured. Chapter 9 distinguishes between four different models: a mandatory repatriation legislation, bottom-up negotiations between indigenous communities and the holding institution that facilitated through the law, a combination of heritage management and repatriation provisions and modern day treaty negotiations. These models have distinct advantages and disadvantages that were elaborated upon in the previous chapter.

What they have in common is that all of them can be constructed to respect relevant human rights guidelines provided that all actors are aware of them and guide their behaviour accordingly. In this aspect the state as body that incurs obligations under international law needs to be proactive. Advance guidance is important in this respect, especially to museums who may not be aware of considering the human rights dimension of their actions given that they do not incur obligations under the relevant treaties. In this respect it should be noted that bottom-up negotiations (model two) should best be combined with ex ante legislative approval in which the state elaborates upon the need to respect human rights standards. To answer the first research question, there are thus different ways to regulate repatriation of sacred cultural heritage in light of international human rights and cultural heritage law standards. The

\footnotetext{
${ }^{2}$ Art.1(a) CDCE.
} 
important element in evaluating the standard is then not so much which model was chosen, but whether the model was drafted and implemented in a way that respects these guidelines.

Does this mean that repatriation legislation can be structured any which way provided these guidelines are respected? The analysis suggests that this is not the case. It appears as if different repatriation mechanisms lend themselves to pursue different goals. Each model has distinct advantages and disadvantages. Instead of recommending one way to regulate repatriation, the author would thus recommend to first take stock of the factors that interact with and shape the repatriation framework: What is the legal-historical context and the legal system in place? What are the legal rules that are in place that a repatriation framework has to adhere to that cannot be changed by adopting a particular model? What is the scale of relocation (number of objects and institutions), the diversity of indigenous communities and their hopes and needs for the process (this will become apparent in the initial collaborative consultation process, see human rights principles above), the willingness (or lack thereof) of museums to repatriate, and the general indigenous rights record within the country? And perhaps most important, in light of all of this information, what is the underlying aim that the actors hope to achieve through the repatriation framework?

The analysis has highlighted how important it is to clarify the aims that the framework seeks to achieve. This then leads us to answering the research question of how repatriation should be regulated with the following proposition: How a repatriation framework is structured should be guided by the consideration which repatriation model has the best chance of realizing the goal that the actors want to achieve and factor in the legal, historical and cultural factors at play. Goals differ and there are different ways in which repatriation can be achieved. Repatriation is a resource-intense endeavor, and therefore every care should be taken to facilitate the achievement of the goals sought. This includes taking care in the consultation, drafting and implementing process to adopt the legal framework to the legal preconditions that cannot be changed as well as to the needs and resources of the actors at play. The discussion of the different models, their advantages and disadvantages and elements to be included can prove to be a useful starting point for this. Not all models lend themselves equally well to achieving all aims. An important first step for all cases is thus to consult and agree upon common objectives that the repatriation framework should (help to) achieve.

This then leads us to the next step. Once consultations have taken place expectations have been spelled out, the chosen framework needs to be drafted and implemented in a way that respects the human rights guidelines elaborated upon in this research. This can be done for all models. The guidelines are, in effect, not dependent on a specific approach. Instead, what is necessary is governmental awareness and willingness to adopt a rights-based approach to their heritage legislation and management, including through - but not limited to - repatriation legislation. For the case of intra-national repatriations, this has the added benefit of aligning repatriations with steps that the government should take to further its compliance with international human rights treaties in any event. The preceding chapters have shown that repatriation and indigenous cultural rights are closely connected. Repatriation legislation cannot only respect but also advance indigenous human rights and achieve very different legislative goals at the same time. At a minimum, any repatriation legislation should thus be rights-based and respect the guidelines derived in chapter 9 . 


\section{Guidelines to incorporate into national cultural heritage law and policy}

The application of human rights standards to the legal context in which repatriation is situated, in particular national cultural heritage law, yielded a number of additional lessons on the national cultural heritage law and policy that affects indigenous rights to their sacred cultural heritage. This answers the second research question posed in this study, which left room for any insights that may be gained by looking so closely at the legal relationship between cultural rights on the one hand and indigenous cultural heritage that rests in museum and/ or state control on the other. Chapters 5 and 8 recommended some changes for the United States and Canada respectively. Generalizing these recommendations, they can be summarized in the guidelines below to answer the second research question:

1. States should encourage museums to ensure that, where custodial agreements are made for sacred cultural heritage and it is not repatriated, the indigenous right to maintain and protect their heritage in accordance with their traditional practices under Art.11(1) UNDRIP is still protected.

2. Heritage legislation and policy has to require FPIC for governmental measures that affect indigenous cultural rights, for example:

a. State archaeological branches that issue excavation permits for potential indigenous sites qualify as governmental actors who have to obtain FPIC.

b. Public museums that exhibit sacred cultural heritage in a way that could lead to its desecration.

c. Any action that interferes with a sacred site that is sanctioned or carried out by a governmental actor can affect indigenous rights. Consultation is a minimum requirement, depending on the impact, FPIC will be necessary. Any legislation or policy measure that affects sacred sites should not unduly interfere with indigenous peoples' rights of access to sites. This is an important measure to respect indigenous rights to manifest their religion.

3. States should take measures to protect and fulfil indigenous access to sacred sites $-\mathbf{a}$ wide margin of discretionary measures is possible.

4. States should take measures to prevent third-person conduct that desecrates indigenous cultural heritage. This includes encouraging private museums not to display sacred objects unless with the FPIC of affected community.

5. States should (better) incorporate indigenous rights into their heritage in export legislation. This includes taking steps to prevent cultural and sacred objects from leaving state territory without the consent of the tribe.

6. States should protect and fulfil indigenous rights to their cultural heritage. The state is under the positive duty to progressively create conditions in which indigenous peoples can control their heritage according to their own traditions. There are many different measures states can take, for example:

a. Include indigenous staff in national/ regional/ local heritage administration to care for indigenous heritage.

b. Encourage museums to employ indigenous staff, support heritage management/ museology studies for indigenous individuals.

c. Accommodate indigenous heritage laws covering indigenous lands within national heritage law schemes. 
7. States can fulfil indigenous rights to their cultural identity by supporting programs that address the results of past discriminatory practices which may continue to affect indigenous rights to preserve and develop their own cultural identity, for example residential schools.

Mostly, these guidelines constitute steps that states should take in their cultural heritage legislation. This is not surprising, given that human rights law imposes obligations upon states. However, they are also measures that museums can decide to take by themselves (without state intervention) if they wish to align their behaviour with human rights standards. For example, museums can make sure to collaborate and consult with indigenous peoples on exhibitions that deal with indigenous cultures and history, including the effects of colonialism. This strengthens the indigenous right to their cultural identity. To respect the indigenous right to their heritage, they can acquire their free, prior and informed consent and guidance on dealing with sacred cultural heritage. Similarly, museum boards can try to staff their institution in a more representative manner and encourage the training and employment of indigenous curators, while keeping an open mind to alternative traditions of what conservation and care-taking might mean. Various museums in both countries have already taken these steps. Some of these measures could also be taken by European museums who might not have the same experience of collaborating with indigenous communities and can take inspiration from their (NorthAmerican) colleagues. 